\title{
Aspectos gerais de uma antropologia da condição histórica e política do homem em Hannah Arendt
}

\author{
Aspectos generales de una antropología de la condición histórica y \\ política del hombre en Hannah Arendt \\ General Aspects of an Anthropology of the Historical and Political \\ Condition of Human in Hannah Arendt
}

\section{Pamella Cossul ${ }^{1}$}

\begin{abstract}
Resumo
Hannah Arendt faz um relato histórico das condições da existência humana com o intuito de responder à pergunta "o que estamos fazendo?". O intuito desse pensamento é analisar de que maneira a mudança dessas condições acabou afetando a vida do homem e a contemporaneidade. A questão da conduta humana continua sendo uma interrogação nos tempos atuais. Assim, a filosofia de Arendt se mantém atual para pensarmos a sociedade contemporânea, visto que seguimos em um crescente das mesmas construções sociais originadas na modernidade. Hannah Arendt apresenta em sua obra aspectos muito importantes sobre a condição política e histórica do homem. Nesse sentido, esta investigação pretende demonstrar a importância das faculdades da memória e do perdão, assim como da capacidade de cumprir promessas no contexto histórico e político para a garantia da pluralidade e dignidade humana.
\end{abstract}

Palavras-chave: Filosofia; Hannah Arendt; História; Política.

\section{Resumen}

Hannah Arendt hace un relato histórico de las condiciones de la existencia humana con el fin de responder a la pregunta "¿qué estamos haciendo? ". La intención de este pensamiento es analizar de qué manera el cambio de esas condiciones acabó afectando la vida del hombre y la contemporaneidad. La cuestión de la conducta humana sigue siendo una interrogación en los tiempos actuales. Así, la filosofía de Arendt se mantiene actual para pensar la sociedad contemporánea, ya que seguimos en un creciente de las mismas construcciones sociales originadas en la modernidad. Hannah Arendt presenta en su obra aspectos muy importantes sobre la condición política e histórica del hombre. En este sentido, esta investigación pretende demostrar la importancia de las facultades de la memoria y del perdón, así como de la capacidad de cumplir promesas en el contexto histórico y político para la garantía de la pluralidad y dignidad humana.

Palabras clave: Filosofía; Hannah Arendt; Historia; Política.

\section{Abstract}

Hannah Arendt gives a historical account of the conditions of human existence in order to answer the question "what are we doing?". The purpose of this thought is to analyze how the change of these conditions affected the life of man and contemporaneity. The question of human conduct continues to be a question of the times. Thus, Arendt's philosophy remains current to think of contemporary society, since we follow in a growing of the same social constructions originated in modernity. Hannah Arendt presents in her work very important aspects about the political and historical condition of human. In this sense, this research intends to demonstrate the importance of the faculties of memory and forgiveness, as well as the capacity to fulfill promises in the historical and political context for the guarantee of plurality and human dignity.

Keywords: Philosophy; Hannah Arendt; Story; Politics.

${ }^{1}$ Mestranda em Ética pela UFSM; Santa Maria; RS; Brasil; pamellacossul@gmail.com 


\section{Introdução}

Hannah Arendt dedicou parte de sua obra a pensar sobre os problemas da modernidade e os motivos pelos quais eles, de alguma forma, se instalaram de modo tão caótico na sociedade. Nesse sentido, os três principais problemas aos quais ela se dedicou são o conceito de homem, as atividades humanas e a questão da política. No livro A Condição Humana (ARENDT, 2017) Hannah Arendt pretende responder à pergunta "o que estamos fazendo?" (ARENDT, 2017, p. 6, grifo meu). Para isso, faz um relato histórico das condições da existência humana da antiguidade até a modernidade. $O$ intuito desse movimento de pensamento é mostrar que algumas importantes variáveis foram alteradas durante o percurso e analisar de que maneira elas acabaram afetando a vida do homem.

A questão da conduta humana continua sendo uma interrogação na contemporaneidade e objeto de estudo de diversas áreas como filosofia, sociologia, psicologia e história. Assim, a filosofia de Arendt se mantém atual para pensarmos a sociedade contemporânea, visto que seguimos em um crescente das mesmas construções sociais e questões originadas na modernidade. Em função disso, ela servirá de fundamento e referência para este trabalho, no qual será analisado o conceito de homem arendtiano e seu papel no mundo.

Este trabalho sustenta que existe um projeto antropológico pautado na esperança de renovação da condição humana por meio da natalidade e pluralidade na obra de Arendt. Entendo antropologia aqui a partir do conceito vaziano de questionamento sobre o homem, permanecente "no centro das mais variadas expressões da cultura: mito, literatura, ciência, filosofia, ethos e política." (VAZ, 1991, p. 9, grifo do autor). A proposta desse projeto é que a condição humana possa ser resultado da variação das construções culturais e ações humanas que proporcionam ao homem exercer mais ou menos sua capacidade política e que essa possui, de alguma forma, um caráter de responsabilidade pelo mundo e pelos homens, que compartilharam ou compartilharão esse mundo conosco.

Para cumprir com os objetivos mencionados acima, o artigo tratará inicialmente da análise histórica proposta por Arendt. Esse exame se dará a partir da antiguidade com a explicação do surgimento da democracia grega e do funcionamento da pólis. Também tratará brevemente sobre a filosofia socrática, platônica e aristotélica e o modo como elas, a partir da noção de homem e de política, afetaram o funcionamento da cidade-estado e configuraram uma antropologia da multiplicidade. Em sequência, analisará um período mais longo da história, que se inicia no medieval e vai até a modernidade. A importância da análise dessas épocas de forma conjunta é a sutileza com que vários acontecimentos e tradições filosóficas 
foram engendrando-se consecutivamente nesses momentos, fazendo com que não seja possível atribuir um resultado especificamente em cada um deles. Porém, a soma desses acontecimentos culminou na modernidade. Ao final da análise o artigo explica qual a consequência desses fatos e mostro como isso afetou o homem, tornando-o frustrado e angustiado, longe de sua condição humana por excelência. De forma que isso se estendeu na contemporaneidade, gerando uma antropologia da identidade, segundo a qual o homem não consegue mais encontrar seu lugar e posição no mundo. Na terceira subseção o artigo apresenta a teoria arendtiana da condição humana, analisando o conceito de homem como ser condicionado, de vida activa (fazendo a distinção das atividades do trabalho, da obra e da ação) e de política. Por último, mostra como esses conceitos se relacionam e apresenta a proposta de um projeto antropológico da pluralidade pautado na renovação do mundo e da condição humana através do ato do nascimento político e da importância da memória, do perdão e da faculdade de cumprir promessas para esse nascimento. A proposta do trabalho é que defender a possibilidade de atualização da antropologia pelo nascimento político, que projeta dá forma a um novo futuro.

\section{Uma proposta de divisão antropológica}

No livro A Condição Humana (ARENDT, 2017), Hannah Arendt faz uma análise da história e da tradição filosófica a partir da antiguidade. Nesse sentido, a proposta nesta sessão será explicar os períodos antigo, medievo e moderno da história mencionados pela autora, bem como as filosofias correntes em cada um deles. Também é feito um exame antropológico desses períodos, a fim de demonstrar que cada um deles acabou caracterizado a partir da ótica do o homem e das ações humanas, dividindo-os nas subseções " a busca pela multiplicidade" e "a busca pela identidade". Essas duas servirão de embasamento para a terceira, denominada "a pluralidade" que é a explanação da teoria arendtiana do homem condicionado. Segundo a qual sustenta ser um projeto antropológico de resgate e renovação da potencialidade política do homem.

\subsection{A busca pela multiplicidade}

A questão do homem, seu modo de vida e sua relação com estruturas urbanas e governos são datados de muito antes do período pré-socrático. Nesse período, os governantes eram considerados criaturas divinas e super-humanas que mantinham o controle através do poder da violência (MORRALL, 1985, p.8). Frente a essa insatisfação com os governos hostis 
deu-se a busca pela liberdade e justiça. Já na pólis grega, os gregos idealizaram um ambiente de debate, consenso e responsabilidades mútuas para superarem o uso da força como justiça e a luta pela necessidade de subsistência. Entretanto:

\begin{abstract}
Para conservar essa superioridade ideal, a pólis tem de incorporar certos princípios de ordem legítima, sem os quais não teria raison d'être justificável. Todo o pensamento político grego gira em torno do debate sobre quais seriam exatamente esses princípios, e como se poderia traduzi-los no mundo prático. (MORRALL, 1985, p.7, grifo do autor)
\end{abstract}

O debate grego sobre os princípios norteadores da democracia grega, que eram inicialmente a liberdade, a igualdade, a imortalidade e a justiça, tem como base geral três linhas dominantes no pensamento antigo. São elas a teologia, a cosmologia e a antropologia. A primeira está ligada à relação da religião com o homem. Nesta a imortalidade, bem-aventurança e a liberdade dos deuses são objetos de desejo do homem que em contrapartida é acometido pela tragédia e pelo destino na terra. A segunda diz respeito à apreciação da ordem da natureza e da estética do mundo, assim como à compreensão das leis universais. A terceira (antropologia) é ligada à tentativa de definir o homem frente à teologia e a cosmologia (VAZ, 1991, p.28-29). Essas linhas de pensamento, conceituadas por Vaz (1991, p.28) como arcaica gregas são elementos importantes da filosofia antiga. Pois formaram e fundamentaram o pensamento de filósofos como Sócrates, Platão e Aristóteles. Estes inspiraram Hannah Arendt em seu pensamento político.

A pólis foi o espaço democrático grego mais tratado na história, apesar de terem existido outros grupos e espaços que prezavam pela democracia na Grécia. Seu estabelecimento se deu no século V a.C., nela estavam aptos a participar os homens adultos e atenienses. Esses eram considerados cidadãos. Isso significa que eles possuíam direito ao voto em Assembleia, bem como a fazer indicações para quaisquer funções na pólis (MORRALL, 1991, p.14). Além disso, organizacionalmente os gregos dividiam suas atividades em dois principais espaços, a esfera pública correspondente à política e a esfera privada que era o ambiente familiar (ARENDT, 2017, p.34). A esfera privada era o ambiente da necessidade, onde a comunidade natural da família se organizava a fim de produzir e manter seus meios de sobrevivência. O homem, antes de adentrar ao ambiente da pólis, devia ter seu lugar no mundo, para então poder tratar da importância do comum e do bem da cidade. Já a esfera pública, em contraposição à necessidade, era o ambiente de liberdade, onde o homem não estava mais "sujeito às necessidades da vida, nem ao comando de outro e nem a comandar" 
(ARENDT, 2017, p.39). O ambiente da cidade-estado era aberto ao discurso e a ação. A partir das funções e leis apropriadas eram feitas as deliberações e as tomadas de decisão sobre os assuntos propriamente humanos. Porém, se faz necessário mencionar que o conceito de igualdade presente entre os homens da pólis é diferente do usado nos dias de hoje, como equivalência; e essa talvez seja a principal questão e crítica à democracia grega:

É verdade que essa igualdade no domínio político tem muito pouco em comum com o nosso conceito de igualdade: significava viver entre pares e ter de lidar somente com eles, e pressupunha a existência de "desiguais" que, de fato, eram sempre a maioria da população na cidade-estado. (ARENDT, 2017, p.39 - 40, grifo do autor)

Assim, algumas questões como a questão da igualdade e o conceito de democracia em comparação com os princípios e leis fundamentais da pólis e as atividades dos cidadãos, foram sendo analisadas e questionadas pelos principais filósofos da época como Sócrates, Platão e Aristóteles, além disso, as definições de homem propostas por eles foram as que mais interferiram no funcionamento da pólis e mais influenciaram na antiguidade e no início do período medieval.

Segundo Vaz (1991, p.34-35), as reflexões de Sócrates sobre a concepção de homem tratam de um princípio interno que visa a excelência. Esse princípio é a alma, que está ligada à procura da verdade e ao cuidado dessa alma através do esforço de unificar a vida reflexivamente. A alma orientaria o homem para as coisas justas ou injustas. Dito de outra forma, o homem socrático tem uma natureza moral em função da alma, está relacionada às questões da vida humana na cidade e à justiça. Além disso, o pensamento socrático está ligado ao enaltecimento do intelectualismo e da introspecção, uma vez que coloca o homem como animal racional (zoón logikón); dotado de palavra e pensamento. A filosofia de Sócrates foi demonstrada tanto pelo seu modo de viver, quanto pelo seu modo de ensinar. No primeiro caso, isso ocorreu porque Sócrates não deixou nenhum registro por escrito de seus pensamentos. No segundo caso, deu-se por meio do método dialético que coloca a questão do conhece-te a ti mesmo e faz com que o homem ao voltar-se para dentro de si encontre as verdades absolutas por meio da razão.

Discípulo de Sócrates, Platão também dedicou sua obra a pensar na definição de homem. Com base nos ensinamentos de seu mestre e influenciado pelas linhas de pensamento arcaicas gregas, Platão elaborou um dos pensamentos mais influentes na história da filosofia. O pensamento platônico foi utilizado posteriormente como alicerce da igreja católica. Platão foi influenciado pelas teses socráticas do homem como ser dotado de logos e possuidor de 
alma. Porém, ele dedicou seu pensamento especificamente à origem e ao destino da alma. A alma, para Platão é "apresentada como movendo-se a si mesma [...] e como 'princípio de movimento"” (VAZ, 1991, p.37, grifo do autor). Esse movimento é ordenado pela realidade transcendente das ideias. A realidade transcendente das ideias garantiria a liberdade do homem sobre o destino porque as ideias transcendentes são mais perfeitas que as formas imperfeitas da natureza e porque a ideia de homem é eterna. Considerando a influência socrática do homem racional possuidor de uma alma, o homem platônico é uma síntese da alma e do corpo. Entretanto, o elemento diferencial de sua teoria é a realidade transcendente, isto é, o reino da ideias absolutas e belas.

Vale lembrar que uma das questões mais importantes da filosofia grega é a questão da imortalidade e da eternidade, que diz respeito à linha de pensamento teológica. Muito antes da democracia ateniense, os gregos possuíam a crença nos deuses do Olympo. Os deuses do Olympo eram considerados imortais e contínuos no tempo. Em contrapartida, os homens eram considerados mortais e efêmeros. Por isso, os homens passaram a se preocupar com a mortalidade, fazendo com que isso viesse a ser uma questão essencial da existência humana (ARENDT, 2017, p.23). A partir disso, duas visões gregas são postas. A primeira é a imortalidade. Esta se relaciona com uma concepção grega arcaica (pré-socrática). A concepção arcaica diz respeito à capacidade humana de produzir coisas que perduram para além de sua própria vida. Desse modo, os homens deixam vestígios de suas vidas mesmo após a morte. Essa concepção está ligada aos assuntos humanos e a vida política na pólis, pois garantiria ao homem a possibilidade de fazer grandes feitos e produzir sua história entre outros homens que pudessem garantir a narrativa e a verdade de sua estória. A segunda visão está ligada ao eterno. Ela nada mais é do que a metafísica consagrada de Platão da realidade transcendente das ideias, na qual a perfeição da ideia é sempre superior à forma inserida no mundo. A partir disso, os filósofos, segundo Arendt (2017, p.22) "haviam encontrado um princípio superior para substituir o princípio que governava a pólis", a saber, a racionalidade das ideias absolutas.

Foi a partir dessas duas visões (imortalidade e eternidade) que as tensões e crises atenienses pioraram, aumentando o questionamento, principalmente dos filósofos, sobre os princípios e atividades dos cidadãos. Segundo Morrall (1991, p.17) a cidade-estado era considerada por muitos como ilógica, pois pretendia ser uma democracia, mas excluía das deliberações mais de cinquenta por cento da população. Desse modo, a democracia grega colidia com os princípios da igualdade e da liberdade. Outro motivo que pode ter contribuído para a queda da pólis foi seu caráter fechado, pois estrangeiros e aliados conquistados em 
guerras não eram convidados a integrar a cidade. Esse fato acabou aumentando a insatisfação e reprovação popular e também dos filósofos que agora passam a contestar com suas ideias a democracia da pólis. Além disso, passaram a ocorrer tensões geradas com invasões e guerras entre as pólis, fazendo com que a cidade ateniense se transformasse "num registro desalentador de guerras à ponta de espadas entre cidades, com o extermínio como castigo da derrota. "(MORRALL, 1991, p.19).

Apesar desses problemas ligados à situação estrutural da pólis, outro importante acontecimento foi marcante para a história da filosofia, o julgamento de Sócrates. Sócrates foi acusado de corromper os jovens com seus pensamentos e de levantar questionamentos sobre a religião da cidade-estado. Isso desagradou os demais cidadãos que prezavam pela ordem da pólis. Por isso, ele foi considerado culpado e condenado a morte. A partir disso, os filósofos tomaram uma posição de "apolitia filosófica" (ARENDT, 2017, p.18, grifo do autor) que acabou distanciando ainda mais a política e a filosofia.

A filosofia passou então a ser definida como atividade da quietude, baseada na noção de que:

Nenhuma obra de mãos humanas pode igualar em beleza e verdade o kosmos físico, que revolve em torno de si mesmo, em imutável eternidade, sem qualquer interferência ou assistência externa, seja humana, seja divina. Essa eternidade só se revela a olhos mortais quando todos os movimentos e atividades humanas estão em completo repouso. (ARENDT, 2017, p.19, grifo do autor)

Esse momento histórico acabou influenciando o pensamento filosófico e político por toda a história, sendo um ponto de referência na discussão arendtiana da situação política da modernidade.

Apesar da importância da filosofia de Platão e Sócrates, Arendt fundamenta da sua análise política da antiguidade, na filosofia de Aristóteles. Ela inicia sua análise em $A$ Condição Humana (ARENDT, 2017) tratando da distinção dos três modos de vida aristotélicos, a saber, "a vida de deleite dos prazeres do corpo, na qual o belo é consumido tal como é dado; a vida dedicada aos assuntos da pólis, na qual a excelência produz belos feitos; e a vida do filósofo, dedicada à investigação e contemplação das coisas eternas" (ARENDT, 2017, p.16, grifo do autor). Essas atividades eram exercidas somente pelas pessoas que tivessem condições de suprir suas necessidades subsistenciais, pois nesse caso, elas não precisavam mais se preocupar prioritariamente com isso. No caso da pólis grega, isso excluía escravos, artesãos e comerciantes que dependiam do seu trabalho para sobreviver. Esses modos de vida estão inseridos em outra divisão, entre as atividades práticas e teóricas. Sendo 
a primeira o bios politikós a vida dedicada a práxis (ação) e a segunda o bios theorétikos dedicado à vida de contemplação.

A conceituação aristotélica do homem como zoon politikón (animal político) torna-se muito importante para entender as atividades humanas, pois, segundo ele, a atividade humana por excelência é a política. A política nos distingue dos demais animais. Na pergunta pela função propriamente humana, Aristóteles chega à seguinte conclusão:

É que o viver parece ser comum também aos vegetais e o que é procurado é o viver peculiar do Humano. Tem, pois, de se fazer uma abstração da função vital de nutrição e de capacidade de crescimento. Segue-se uma certa função vital perceptiva, a qual parece ser comum ao cavalo, ao boi e a todo ente vivo. Resta, então, uma certa forma de vida ativa inerente na dimensão da alma que no Humano é a capacitante de razão. A possibilidade capacitante de razão do Humano manifestase de duas maneiras: Uma, através da obediência ao sentido orientador, a outra, quando já o possui, através da ativação do seu poder de compreensão. (ARISTÓTELES, 2009, p.27)

Essa capacitante razão mencionada, só se dá como atividade especificamente humana na medida em que é exercitada, aplicada na vida do homem a fim de torná-lo virtuoso em tal capacidade. Na Ética a Nicômaco (ARISTÓTELES, 2009) trata da questão do bem. Segundo ele todas as ações possuem um fim, que é o bem supremo. A política é a atividade humana mais autêntica, pois é capaz de dar realidade ao conhecimento teórico e de determinar quais conhecimentos e aperfeiçoamentos são necessários aos estados, às classes e às pessoas. Para Aristóteles o sumo bem é o bem humano por excelência, aquele que se conserva para além da vida dos indivíduos e se garante como bem do povo. O sumo bem é o mais belo e mais próximo do que é divino (ARISTÓTELES, 2009, p.18). Contrapondo Platão, Aristóteles sustenta que os conceitos políticos e éticos, que se manifestam em ações humanas, são definidos por convenção, pois o fato de gerarem opiniões díspares e possibilitarem margens de erro demonstra a ausência de uma natureza absoluta.

Temos então aqui, os três principais conceitos de homem da antiguidade. O homem racional possuidor de alma socrático. O homem, síntese corpo e alma de Platão que tem uma essência absoluta na realidade transcendente. E o homem propriamente político de Aristóteles. Apesar de abordagens diferentes, defendo que os filósofos clássicos mencionados conceituam o homem a partir de uma antropologia da multiplicidade, ou seja, de uma abordagem de que somos todos iguais enquanto espécie. Essa igualdade está relacionada a uma única essência/natureza determinante que nos diversifica das espécies animal e vegetal. $\mathrm{Na}$ base dessa abordagem, estão as leis da lógica que nos ensinam que "para determinar a essência de uma coisa, é preciso situá-la primeiro no seu gênero, ou seja, na classe à qual ela 
pertence, aquelas cujos integrantes compartilham as mesmas determinações essenciais" (NOVAES, 2009, p.38). Mas não é apenas a lógica que está na base dessa abordagem, pois se pode afirmar que também há uma antropologia. Essa antropologia fundamenta-se em conceitos universais e imutáveis, os mesmos conceitos que foram utilizados para fundamentar o período medievo e a expansão da igreja católica no mundo.

\subsection{A busca pela identidade}

Após a invasão da Grécia pelos romanos, parte da cultura grega foi aderida pelos romanos. A filosofia foi um desses elementos culturais. Nessa adesão, os neoplatônicos foram os filósofos que mais contribuíram para a divulgação da filosofia grega, fazendo com que o pensamento platônico fizesse parte da cultura romana. Essa apropriação cultural influenciou posteriormente no uso da teoria de Platão como fundamento dos princípios do cristianismo. O que acabou sendo base da construção de uma nova noção de mundo. A noção de que estamos nesse mundo terreno só de passagem e ele não um fim em si mesmo, mas sim um meio de chegar ao verdadeiro mundo de Deus, o paraíso eterno.

A propagação dessas novas crenças fez com que as pessoas deixassem de lado ainda mais a preocupação política e as atividades humanas por excelência tratadas por Aristóteles. Também a ideia de um mundo transitório, motivo só de passagem como trata a religiosidade cristã, fez com que as pessoas perdessem a motivação à liberdade política e a imortalidade mundana, abandonando o antigo empenho pela vida política e pela vida de ação. Assim, cada vez mais as pessoas foram privando-se das relações na esfera pública, se tornando fechadas ao seu íntimo e ao seu egoísmo.

É na idade média, e isso se traduz na Suma Teológica (AQUINO, 1936) que ocorre a inversão da esfera pública como necessidade. São Tomás de Aquino altera importância da vida ativa proposta por Aristóteles. Considerando-a inferior à contemplação. A vida política (vida ativa) torna-se uma necessidade humana para alcançar a liberdade da vida contemplativa que possibilita a apreciação do absoluto e eterno, que é o caso da verdadeira vida divina, sendo essa divina e superior. Segundo Aquino a vida contemplativa era considerada superior à ativa por possibilitar o puro exercício da razão dado por Deus ao homem como fator de diferenciação dele em comparação com os animais:

A vida contemplativa supõe uma certa liberdade da alma. Pois, como diz Gregório, a vida contemplativa nos dá uma certa liberdade do espírito, aplicado às coisas eternas, sem cogitar das temporais. E Boécio: As almas humanas hão de 
necessariamente ser mais livres, quando se mantêm na contemplação do pensamento divino; menos livres, ao contrário, quando recaem no mundo dos corpos. Por onde é claro, que a vida ativa não dá diretamente regras, à vida contemplativa; mas, dispondo para ela, ordena a prática de certos atos, servindo assim, antes, à vida contemplativa do que lhe dando regras. Por isso diz Gregório, que a vida ativa é considerada escravidão e a contemplativa, a liberdade. (AQUINO, 1936, Questão 182, art. 1, Resposta à Segunda Objeção)

A vida contemplativa permitiria o homem bastar-se a si mesmo e dedicar-se às coisas de Deus. Já a vida política e a ação humana neste mundo eram consideradas como meios de garantir a subsistência através do trabalho, a fim de possibilitar a realização de obras divinas para então alcançar a contemplação no paraíso de Deus. Daí a troca da inserção na esfera pública pela volta à privação do lar. Segundo Arendt, neste período a pergunta pela natureza do homem é cessada em função da existência do Deus eterno:

O problema da natureza humana, [...] de Agostinho, parece insolúvel, tanto em seu sentido psicológico individual como em seu sentido filosófico geral. É altamente improvável que nós, que podemos conhecer, determinar e definir as essências naturais de todas as coisas que nos rodeiam e que não somos, sejamos capazes de fazer o mesmo a nosso próprio respeito [...] se temos uma natureza ou essência, então certamente só um deus poderia conhecê-la e defini-la. (ARENDT, 2017, p.13)

O homem passou a cultivar mais seus sentimentos do que a iniciativa de tomar atitudes que influenciem na vida comum. Então na medida em que essa problemática da natureza humana e esse sentimento e introspecção avançaram, as novas ciências retornaram a vê-lo como objeto de estudo, o homem passou a ter novamente as suas origens, seu modo de vida e sua missão questionados. Dessa forma, é possível perceber como a política como considerada pelos gregos foi destruída pela ascensão da igreja e seus princípios de auto-salvação até a modernidade.

Com a modernidade, se deu o aparecimento da sociedade. Essa tornou incompreensível a diferença entre público e privado. Alterando seu significado "a sociedade exige sempre que os seus membros ajam como se fossem membros de uma enorme família que tem apenas uma opinião e um único interesse. " (ARENDT, 2017, p.48). Ou seja, o social tentou abarcar o público e o familiar (privado) e acabou destruindo ambos. O âmbito das necessidades se torna assunto comum e os assuntos públicos até então viram administração de riqueza. O homem passa a não ter privatividade alguma, sobrando somente seu individualismo. Sobre isso, Arendt menciona a rebelião do coração tratada por Rousseau contra a perversão do coração humano pela sociedade (ARENDT, 2017, p.47). Isso fez com que o homem passasse a se dedicar mais às questões subjetivas e íntimas, atingindo o ápice do 
caminho para dentro de si mesmo em comparação com o estar entre os demais concebido pela vida política.

O espaço comum fora substituído pela administração de uma grande comunidade familiar, onde o modo de vida do homem passou a ser controlado. Seus desejos e anseios são de alguma maneira, programados a fim de serem padronizados, gerando um cenário de conformismo e alienando as pessoas a fim de que elas possam ser controladas mais facilmente conforme os objetivos pretendidos pelo governo. A sociedade não admite a espontaneidade. Basicamente, a liberdade de discurso e de ação presentes na pólis grega, foi substituída pelo controle e alienação de massas na modernidade. O predomínio da atividade do trabalho acabou gerando uma sociedade de trabalhadores que produzem incessantemente e que são obrigados a consumirem da mesma forma para garantir a abundância da produção e de seus empregos. Esse predomínio do trabalho pode ser percebido também na tradição filosófica, através da concepção marxista de homem. Sua teoria defende que a matéria é a única realidade existente e o homem é compreendido pelas relações sociais construídas a partir da necessidade e da subsistência:

Do ponto de vista da Antropologia, o que sobreleva é a relação do homem com a natureza por meio do trabalho e a humanização sob o aspecto de autocriação do homem no processo de transformação da natureza pelo trabalho. As mudanças nas formas de trabalho constituem os indicadores básicos da mudança das relações de produção e das formas sociais em geral do intercurso humano. O trabalho é, portanto, o fundamento antropológico das relações econômicas e sociais em geral. (MARX, 2013. p.48)

O diferencial apresentado por Marx do homem em comparação com os animais é que o homem é capaz de transformar a natureza por meio do trabalho. A partir da motivação para construir a realidade do mundo e sua história através dele. Os homens produzem os seus próprios meios de subsistência (MARX; ENGELS, 2001, p.24). Além disso, a obra de Marx trata exclusivamente de como essa natureza trabalhadora do homem fora aproveitada e corrompida em função do acúmulo de capital e da alienação dos homens frente à exploração da sua natureza. Ainda assim, a teoria marxista comete o mesmo erro de atribuir uma concepção "natural" ao homem, vendo-o somente enquanto espécie. Além das necessidades biológicas, o homem ficou sujeito às necessidades subjetivas de felicidade, de compra, e de estilo de vida ditadas por essa grande administração chamada de governo. Essa administração se manifesta e atua com interesses exclusivamente econômicos, diferente dos interesses da política grega. 
Muitos dos problemas da contemporaneidade, como a desigualdade social, o consumo desenfreado e os conflitos de poder, estão relacionados à perda da capacidade política no homem. Mas também não se pode culpar o próprio homem. É possível que as pessoas também não estejam conseguindo perceber isso. Os mecanismos de alienação e expressivo controle de comportamento que foram inseridos em suas vidas impedem esse olhar atento. Além disso, trabalhando em condições desumanas, exploratórias e com dificuldade de sustentar-se, quem poderá pensar nos outros e querer conviver com os demais, pensando sobre a coletividade do mundo e resolvendo os problemas através de um espaço de discurso e ação? O capitalismo, bem como o modo que o trabalho é organizado nos dias de hoje, enriquece poucos e abandona muitos, iludindo as pessoas de que elas estão sendo amparadas e possuem oportunidade através de direitos e benefícios sociais. A contemporaneidade é a condição humana da identidade, onde o homem alienado passa a buscar dentro de si o significado da sua vida e de si mesmo. A partir disso, torna-se um homem angustiado e frustrado, distante da sua condição humana por excelência que é a política. Essa frustração acaba sendo objeto de estudo das ciências do comportamento como a psicologia, que pretendem definir o homem a partir dessa busca interna, mas para Arendt é um problema político e filosófico. Pois o homem já não exerce mais sua humanidade através da ação e do discurso e das relações com seus semelhantes.

\subsection{A pluralidade}

Hannah Arendt em seu livro A Condição Humana (ARENDT, 2017) faz uma análise histórica da antropologia e da política. Essa análise possui o propósito de repensar o conceito do homem a partir das experiências modernas. Segundo Arendt, trata-se de "pensar o que estamos fazendo" (ARENDT, 2017, p.6, grifo do autor). Essa reflexão sobre nossas atividades trata de como as ações e produções humanas acabaram condicionando o homem durante a história, alterando o seu modo de viver e também a potencialidade da sua capacidade política.

Diferente das tradições filosóficas tratadas nesse artigo, Arendt concebe o homem de uma maneira inédita na história da filosofia, não sendo mais como ser de essência ou natureza absoluta. Hannah Arendt trata da condição humana, essa:

Compreende mais que as condições sob as quais a vida foi dada ao homem. Os homens são seres condicionados, porque tudo aquilo com que eles entram em contato torna-se imediatamente uma condição de sua existência. (ARENDT, 2017, p.11) 
Quando fala que a condição humana compreende mais do que as condições dadas aos homens, Arendt está fazendo uma crítica às teorias tradicionais. Segundo ela, essas teorias concebem o homem a partir de uma natureza anterior ao próprio homem, como as leis da lógica e da biologia mencionadas anteriormente nesta sessão. Parece bastante óbvio que essas leis são invariavelmente aplicadas ao homem. Porém, Arendt defende que não são elas as responsáveis por caracterizar o modo com que o homem vive e se relaciona com o mundo, mas sim o objeto da própria relação, o mundo (e as coisas existentes nele).

Hannah Arendt, influenciada por Aristóteles, divide a vida humana em dois modos. A vida activa e a vida contemplativa. A vida contemplativa aqui tem o mesmo sentido de introspecção e dedicação ao pensamento puro do bios theoretikos aristotélico, por isso, não é o foco da teoria arendtiana. A grande razão de ser da obra arendtiana é abordagem do modo de vida ativo, ou vida activa proposta pela filósofa.

A vida activa é dividida em três atividades humanas, o trabalho, a obra e a ação (ARENDT, 2017, p.9). O trabalho diz respeito aos processos naturais do corpo humano e principalmente das formas de manutenção desse corpo a fim de sanar as suas necessidades básicas. A obra está ligada à produção e fabricação de artifícios, ou seja, a manipulação da natureza pelo homem e construção de um mundo propriamente humano. E por último a ação, que é um dos conceitos mais importantes na teoria arendtiana. Para Arendt, a ação é única atividade especificamente humana e a única capaz de abrigar a política. Ela é a única atividade que se dá diretamente entre os homens, e sem eles não seria possível. Essa relação entre os homens garante a pluralidade, que a noção de que são os homens (singulares) que habitam o mundo e não o homem (espécie). A pluralidade é "especificamente a condição não apenas a conditio sine qua non, mas condition per quam - de toda a vida política. '” (ARENDT, 2017, p.9, grifo nosso). Daí a importância da atividade da ação para a teoria arendtiana. Essa pluralidade, segundo Arendt é o que politicamente nos tornas iguais, diferentemente do princípio de igualdade grega tratado anteriormente. Aqui, os homens são iguais na condição de seres humanos, daí o princípio democrático. Além disso, ela também ressalta a importância da singularidade para o agir político e responsabilidade sobre os homens, na medida em que "ninguém é jamais igual a qualquer outro que viveu, vive ou viverá" (ARENDT, 2017, p.10, grifo nosso). Essa ideia de valorização da singularidade humana está ligada à política pela esfera pública.

A esfera pública é uma construção humana que nos mantém na companhia dos demais através do discurso e da ação, mas que é também capaz de nos separar e reorganizar de forma sensata pelo mesmo mecanismo (discurso e ação) quando necessário, que é o caso dos 
conflitos. A esfera pública é o espaço do debate e da crítica em função de um objetivo democrático. O bem comum de todos os seres humanos singulares. Hannah Arendt mantém a ideia grega de política como superação da mortalidade humana. Ela considera que a ação "cria a condição para lembrança" (ARENDT, 2017, p.11). O homem ao ingressar na esfera pública vive sua capacidade mais humana, e por meio dela pode tomar decisões e construir sua estória pública, imortalizando-se nas narrativas e deixando um legado para seus demais semelhantes, a fim de "estabelecer uma biografia" (ARENDT, 2017, p.119).

Hannah Arendt faz uma análise antropológica da história a fim de compreender as condições do homem em cada período histórico e as definições feitas pelos principais filósofos de cada época. Isso é sustentado pelo fato dela citar, a todo o momento em $A$ Condição Humana (ARENDT, 2017), não só as teorias filosóficas e seus respectivos autores, mas o modo como o homem vivia a partir dessas mudanças de paradigmas. E quais as consequências fundamentais dessas mudanças na condição humana. Nesse movimento de transpassar a história, Arendt acaba influenciada por alguns pensamentos, como a política aristotélica e repelida por outros, como a questão do social.

Arendt não idealiza a pólis como o ambiente democrático mais promissor e nem defende a exclusão das maiorias, como escravos e mulheres, conforme ocorria no período antigo. Sobre isso, ela inclusive denuncia a modernidade na medida em que coloca que:

\footnotetext{
A condição de escravidão não é hoje inteiramente manifesta; e por não parecer tanto, torna-se muito mais difícil notá-la ou lembrá-la [...] o homem não pode ser livre se ignora estar sujeito à necessidade, uma vez que sua liberdade é sempre conquistada mediante tentativas, nunca inteiramente bem-sucedidas, de libertar-se da necessidade. (ARENDT, 2017, p. 149).
}

Segundo Arendt a escravidão era a sujeição às necessidades aliada à condição de violência, enquanto que hoje os esforços e penas do trabalho são, em sua maioria, reduzidos pelo processo de mecanização. Fazendo com que sentimento de exploração seja reduzido pela ausência de dor física.

Outro fator que evidencia a posição arendtiana é a diferença conceitual entre o princípio de igualdade grego, que fora aqui explicado, e a igualdade enquanto espécie. Além disso, a simpatia e inspiração que ela parece demonstrar à noção política grega estão ligadas à sua utilização dos conceitos antigos de práxis, como um resultado do pensamento teórico e das noções da liberdade e de imortalidade. Outro fator que parece corresponder a essa simpatia é a crítica incisiva ao período entre o medievo até a modernidade. Na verdade, essa problemática está ligada a análise da condição humana e à potencialidade da política. Para 
Arendt a organização dos homens e os princípios da antiguidade tornavam a condição humana, através de uma antropologia da multiplicidade, favorável ao estabelecimento de um espaço político, mesmo com defeitos e falhas que acabaram por segregar parte das pessoas. Já a partir do período medievo e renascentista, as atividades humanas diminuíram em função da religião, o que tornou a vida mais privada e introspectiva, alterando a condição humana e assim a potencialidade política. É finalmente na modernidade o cerne da crítica arendtiana, pois neste período a condição humana não fora modificada por uma série de eventos contingentes e culturais, mas sim de forma proposital. Esse propósito nada mais é do que a ascensão do social, a alienação das massas e o acúmulo de riqueza propostos na modernidade, que acabaram por culminar na contemporânea condição humana da identidade.

Apesar do panorama atual da condição humana e da política, a teoria arendtiana parece conter em si uma esperança, a qual chamarei de um projeto antropológico da pluralidade. A política arendtiana é um espaço no qual se dão, a partir do modo de vida ativo, as atividades do discurso e da ação. Esse espaço possui um princípio sem o qual não poderia existir, que é a pluralidade. A pluralidade é o conjunto de seres humanos iguais em espécie, mas singulares e distintos. De forma que nenhum jamais será repetível. Essa pluralidade está ligada à noção de mortalidade, na medida em que o homem se imortaliza no espaço político pela sua contribuição e seus feitos pelo comum. Essas ações possuem um caráter imprevisível, ilimitado e irreversível na medida em que afetam outros homens capazes de agir e reagir a esses feitos e de forma que nem todas as reações consequências podem ser previstas quando se trata de assuntos humanos (ARENDT, 2017, p.236-237). A ação só possui seu significado quando é feita, acabada. Daí a importância do discurso e da deliberação a partir da liberdade de pensamento, de forma que se tente reduzir quaisquer danos. Ainda assim, Arendt considera que os resultados dessas ações possam ter duas soluções, a primeira é a capacidade de cumprir promessas e instaurar o futuro, garantindo uma segurança na tomada de decisão e a outra é a capacidade de perdoar os maus feitos. Segundo Arendt "se não fôssemos perdoados, liberados das consequências daquilo que fazemos, nossa capacidade de agir ficaria, por assim dizer, limitada a um único ato do qual jamais nos recuperaríamos" (2017, p.293). Nesse sentido, é preciso perdoar para que a novidade se instaure e novos feitos sejam realizados para o bem comum.

Junto a essa capacidade de perdoar, está o conceito de natalidade, e daí a esperança arendtiana na humanidade: 
O milagre que salva o mundo, o domínio dos assuntos humanos, de sua ruína normal, "natural" é, em última análise, o fato da natalidade, no qual a faculdade da ação se radica ontologicamente. Em outras palavras, é o nascimento de novos seres humanos e o novo começo, a ação de que são capazes em virtude de terem nascido. (ARENDT, 2017, p.306, grifo do autor)

Daí a proposta de um projeto antropológico. Na medida em que o mundo se renova e novos homens chegam ao mundo, a condição humana também se altera. Tornando a política sempre uma atividade em potencial na esfera pública, na medida em que "onde quer que as pessoas se reúnam, esse espaço existe potencialmente.” (ARENDT, 2017, p.247). Então, se os princípios que gerem a política fizerem parte da vida do homem, a condição humana por excelência, que nos torna mais próximos da nossa própria humanidade, mesmo em períodos conturbados como os da atualidade, permanece sempre como potencial e vir a ser. Garantindo a esperança de tempos mais humanos.

\section{Conclusões}

Como mencionado anteriormente, a discussão do conceito de homem e sua relação com a política é muito conhecida e foi tratada por muitos filósofos nos diferentes períodos da história. Apesar disso, as teorias propostas até a modernidade parecem não abarcar a realidade das ações e motivações humanas. Nesse sentido, Arendt coloca a pergunta "o que estamos fazendo? " como um momento crítico de reflexão. Essa reflexão é feita a partir de um regresso histórico a fim de entender a cadeia causal da sociedade contemporânea. A partir da análise das principais teorias sobre o homem e sobre a política; e da condição humana em cada um dos períodos históricos da antiguidade até a modernidade, podemos ver como essas abordagens de relacionam e se modificam a partir as ações humanas. Essa relação é o objeto de estudo da antropologia, que é o centro desse artigo e da pergunta arendtiana. A expressão "O que" representa um produto, um caráter de coisa; a palavra "estamos" refere a um sujeito, o qual nos vale perguntar: Quem é? E o "fazendo" é o verbo da ação em prática no momento presente. Essa pergunta revela o caráter da condição humana e o modo como ela é relacionada e interfererida por exatamente todas as coisas. O ser humano está se distanciando da sua humanidade, da sua capacidade política. A vida activa atual é pautada no trabalho, na necessidade de manter a própria vida. Isso faz com que a humanidade vire somente um potencial. Onde o animal político passa a ser só animal; nascendo, trabalhando para suprir a si mesmo, se reproduzindo e morrendo. Mas Hannah Arendt traz a novidade do homem condicionado, e com ele a possibilidade de renovação do homem através do nascimento. Essa 
renovação potencial é também a esperança política e se manifesta como um projeto antropológico na medida em que os novos sujeitos possam vir a se relacionar e agir condicionados pela pluralidade, a fim de perdoar as consequências do passado e do presente, além de prometer a possibilidade de um futuro o qual o legado da humanidade permaneça imortal.

Esse trabalho aborda uma interpretação um tanto ousada da teoria arendtiana e intenciona uma proposta ambiciosa que não se esgota nesse presente trabalho. Ainda assim é incapaz de esgotar o conteúdo dessa particular obra arendtiana que é A Condição Humana (ARENDT, 2017) que é muito rica e didática sobre muitos problemas da história da filosofia e da humanidade. Há muito a ser explorado, pesquisado e discutido na teoria arendtiana, principalmente na área antropológica, devido à possibilidade de uma implicação ética e moral desse homem condicionado. Mas essa abordagem pretende ser mais bem desenvolvida em um outro momento, num futuro próximo.

\section{Referências}

AQUINO, São Tomás de. Suma Teológica. Tradução de Alexandre Correia. 1. ed. Brasil. 2017.

ARENDT, Hannah. A Condição Humana. Tradução de Roberto Raposo. 13. ed. Rio de Janeiro: Forense Universitária, 2017.

ARISTÓTELES. Organon. Tradução de Piranhanda Gomes. 1. ed. Lisboa: Guimarães Editores Lda, 1985.

ARISTÓTELES. Ética a Nicômaco. Tradução de António de Castro Caeiro. 1. ed. São Paulo: Editora Atlas S.A., 2009.

BOEHNER, Philotheus; GILSON, Etienne. A História da Filosofia Cristã. 2. ed. Rio de Janeiro: Vozes, 1982.

VERNANT, Jean Pierre. Mito e Pensamento entre os Gregos. 2. ed. Rio de Janeiro: Paz e Terra, 1990.

MARX, Karl; ENGELS, Friedrich. A Ideologia Alemã. Tradução Luis Cláudio de Castro Costa, $2^{a}$ tiragem. Brasil: Martins Fontes, 2001.

MORRALL, John B. Aristóteles. Tradução de Sérgio Duarte. 2. ed. Brasília: Editora Universidade de Brasília, 1985.

VAZ, Henrique Cláudio de Lima. Antropologia Filosófica. 2. ed.. São Paulo: Loyola, 1991. 
NOVAES, Adauto. As quatro concepções de homem. 1 ed. Rio de Janeiro: Editora Agir; Edições SESC-SP, 2009. 